\title{
Employer Branding and Employee Engagement: An Evidence from Banking Sector
}

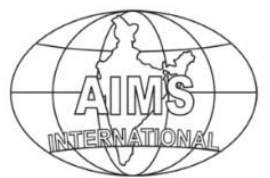

DOI: $10.26573 / 2020.14 .2 .4$

Volume 14, Number 2

May 2020, pp. 115-127

\author{
Anchu P. R \\ Santhosh. P. Thampi \\ Mahatma Gandhi University \\ (anchupr@gmail.com) \\ (drspthampi@gmail.com)
}

In the current days of tough competition there is a need for organisations to be more efficient to remain sustained in the market. Organisations adopt many strategies to gain competitive advantage and operational excellence. They need talented employees for the effective functioning and implementation of such strategies. Employer branding plays an important role to attract and retain employees in an organization. The study focuses on the relationship between different dimensions of Employer Branding and its effect on Employee Engagement among bank employees. 139 respondents from the select banks were contacted for the study. The data was collected using self-administered structured questionnaires. The Employer Branding was measured in terms of Economic value, Social value, Developmental value and Reputation value. The study also tries to find out whether the demographic variables make any difference in exhibiting Employee Engagement. Kolmogorov-Smirnov test was used for testing the normality of the sample. Independent sample t-test, Oneway ANOVA, Karl-Pearson's Correlation and Multiple Regression analysis were used for analysing the data. The results revealed that there is a significant positive relationship between Employer Branding and Employee Engagement.

Keywords: Employer Branding, Employee Engagement, Banking

\section{Introduction}

The term 'brand' is generally associated with the products and services of an organisation. But now it is widely used for almost everything related to an organisation including workplace, skills, content, and the organisation itself. Employer branding is what an organisation carries as a unique identity. It helps to distinguish an organization from its competitors. Employer branding has the potential to influence many factors.

The banking sector is an area where tremendous growth is always expected and experienced. Rising income has increased the need for banking services which created a boom specifically in terms of usage rate, transactions etc. Customers are looking forward to better banking services. Maintaining loyal customers is considered as a herculean task for bankers. Committed employees can enhance customer loyalty by way of making a bank more approachable. Employer Branding can create and enhance the commitment of employees that can make employees 
more committed. It can help to make employees more engaged and in turn result in customer loyalty in the banking sector. The term Employer Branding was first coined in 1990 by Tim Ambler and Simon Barrow. Employer Branding can be termed as selling a company to its employees. It is the delivery of an organization's culture as the best employer in the competitive market. It helps to bind employee-employer relationship stronger. It helps to enhance the Employee Value proposition and encourages employees to increase productivity and thereby embrace the success of the organisation. Employer Brand was defined as the package of social, psychological and functional benefits provided by the employment and identified within the employing company (Ambler \& Barrow, 1996). The use of branding principles in human resources is known as Employer Branding (Backhaus \& Tikoo, 2004). Employees are willing to work with a reputed organisation in a way similar to customers buying branded products. Employer Branding can be measured in several dimensions.

- Interest Value: It determines the degree of appearance of an employer who provides working conditions with innovation and opportunities

- Social Value: It elucidates the character of an organization providing a work environment with corporation and relation among co-workers

- Economic Value: It determines the attraction of an employer who provides a decent remuneration and profits

- Development Value: It estimates the degree of attractiveness of an employer providing career development

- Reputation value: It determines an employee's collective opinion regarding an organisation

- Application Value: It determines the degree of attraction of an employer providing the chance to apply what is learned.

Employer Branding can result in the willingness of employees to give more than what is expected from them. This can lead to a discretionary behaviour called Employee Engagement. Many studies have revealed a relationship between Employer Branding and Employee Engagement. A study by Ahmad and Daud (2016) in Malaysian SME-ICT firms tried to study the relationship between Employer Branding and Employee Engagement. The result revealed a positive significant relationship between Employee Engagement and Employer Branding. Another study by Khalid and Tariq (2015) found that there is an effect on Employer Branding and recruiting process. Employer brand is usually associated with the best brand of employer. Rasheed et al. (2013) in their study revealed that engaging employees is an important factor as it brings benefits to an organisation such as lowering employee turnover, improving organisational commitment, raising productivity and performance, and increase customer satisfaction. A report by Hewitt (2016) stated that in most organisations about 65percent of employees are engaged while 35percent are passive or actively disengaged. It is in this context that this study aims to find out whether Employer Branding has any effect on engaging bank employees of State bank of India, ICICI and HDFC banks in Thiruvananthapuram District of Kerala, India. The study also looks into the relationship between demographic factors and Employee Engagement. 


\section{Literature Review}

Employer Branding (EB) was coined by Tim Ambler and Simon Barrow in 1990. Employer branding is a package of functional, economic and psychological benefits for its target audience. Sullivan (2004) has further defined Employer Branding as a focused, long-time method to manage the perceptions of employees, and associated stakeholders about a firm. Brand name or branding of the employer has an effect on attracting employees towards the organisation. This will make the organisation as a preferred place for its employees. It also helps the organisation to be able to attract and retain a pool of talents into the organisation. During the ' $90 \mathrm{~s}$, companies were engaged in recruiting the best talent and retaining them so that they could be the best employer among the competitors. For this, companies started adopting brand management strategies and made them aligned to Human Resource strategies so that competitive advantage can be achieved. Another reason of the emergence of this concept in the $90 \mathrm{~s}$ is the introduction of the Internet. The Internet provided employees and prospective candidates with a high level of information about the company, making it important for the company to create an Employer Brand. Employer Branding is gaining interest among academics, as well as practitioners. Simon Barrow and Tim Ambler defined it as the package of all benefits provided by the employer and identified by the employee. By having good Employer Branding dimensions, organisations can manage employee's perceptions of their organizational culture and influence commitment level employees will have towards the organisation. Backhaus, K. \& Tikoo, S. (2004) in their study said that Employer Branding is a process consisting of three steps including, developing a conceptual framework about the organisation to prospective and current employees which can be defined as the value proposition of the firm. Secondly to market this value proposition to attract potential employees and finally delivering the brand promise given to the employees so that it gets incorporated into the organisation's values. When the employees are aware of this value proposition and brand promise they show some discretionary behaviour and more passion to work. This discretionary behaviour associated with employees can lead to Employee Engagement.

Many organisations are concerned about Employee Engagement (EE). A universal definition of Employee Engagement was given by Kahn (1990) as the harnessing of organization members selves to their work roles. Engagement is all about where people employ and give themselves physically and emotionally during their organisational role performances. Employee Engagement has been emerging as a popular concept. It has gained high priority among several organisational members (Bhatla, 2011). Employee Engagement has gained attention among academic researchers due to its holistic impact on every area of research (Larkin, 2009; Sharma \& Anupama, 2010). The Gallup Organization states that it is characterised by enthusiasm and passion to work (Vance 2006). The Gallup Organization (2006) has elaborated that engaged employees are very passionate about their work and have a profound connection with the company they are working with. They help in achieving innovation and ensure the success of the organisation. In the UK, the CIPD (2007) refers to it as 'passion for work' and the willingness to go the extra mile. Buckingham (1999) has identified in his study that 'Actively engaged' employees are enthusiastic and energetic, and are extremely committed to their organization. 'Not engaged' are indifferent and are neither positive nor negative towards their 
organization. The 'Actively disengaged' ones are virtually against everything. AON survey (2018) on trends in Global Employee Engagement examined 1000 companies around the globe and took response from 8 million employees. They found that rewards and recognition, senior leadership, career development, employee value proposition and enabling infrastructure are the strongest drivers of engagement globally. Harvard Business Review Analytical Services, in a study on Employee Engagement examined the Employee Engagement drivers. From the study the most impactful Employee Engagement Drivers identified were - recognition, senior leadership, employee-employer communication and job clarity. Robinson, Perryman, and Hayday (2004) in their study revealed that Employee Engagement is a positive approach of employees towards the organization. For Employee Engagement to work profoundly employee-employer relationship must be nurtured. It is a two-way connection between employees and the organization. If the engagement level is higher, organisation would try to develop and engage employees more. Engaged employees will work for the organisation with more enthusiasm and passion so that individual and organisational goals are achieved.

The relationship between Employer Branding and Employee Engagement and its antecedents has been studied by several academicians over time. Sokro (2012) in his study has observed that Employer Branding is significantly positively related to attraction and retention of employees. Jiang and Paul (2011) found that Employer Branding determinants such as, economic value, developmental value and social value can boost up the brand equity and organizational attractiveness to a higher level. Schlager et al. (2011) have identified five main dimensions of Employer Branding namely economic value, developmental value, social value, diversity value and reputation value. The study indicated a positive significant correlation between these dimensions and Employee satisfaction. Collins and Stevens (2002) empirically analysed that employees are attracted towards organisation for many reasons and the major factor is the reputation of the company. A study on thirteen banks operating in Saudi Arabia done by Nisar Ahamad Nalband and Mohammed A. Al Awadh (2017) found that Employer Branding practices help in retaining the employees. The study reveals that Employer Branding practices have a significant impact in the Saudi Arabian banking sector in retaining their employees. Employer Branding practices gives a positive impact on the employees of the organisation. The authors also reveal that a company having efficient Employer Branding practice can attract and help to retain employees. Amir Dabirian and Jeannette Paschen (2019) in their study examine the effect of Employer Branding in IT companies. The authors try to reveal the challenges faced by IT employees and discuss that Employer Branding practices can help to make an organisation a better place to work with. A content analysis based on 15000 employee reviews, explains that Employer Branding can help to retain employees in this competitive business era. According to Sutherland, Torricelli, \& Karg (2002), for an organisation to have success it must recruit and retain the best pool of talent. Employer Branding can help to attract potential candidates and retain them for a long time and envisage the success of the organisation. Fulmer, Gerhart and Scott (2003) have discussed Employer Branding in their study on Employer Branding practices on top 100 US organisations. They revealed that Employer Branding practices can improve workforce attitudes and can also improve organization's performance. Rathore (2014) examined the effect of 
Employer Branding among the companies including, TCS, Google, McDonald's and British Airways. The study found that all these companies are effectively using branding dimensions in different ways and found that positive Employer Branding enhances the image of the organization. It also helps in recruiting and retaining potential employees. Evans Sokro (2012) examined the relationship between employer brand and retention with the mediating effect of Employee attraction in the banking sector in Ghana. They found that the brand name of organizations affects the decision of potential employees to join an organisation and existing employees to remain in the organisation. Pallavi Mehta and Khushboo Sharma (2014) examined Employer Branding effects on faculties of management institutes in Udaipur. The study revealed a positive significant impact of Employer Branding on employee satisfaction and in turn retaining the employees. The research states that organisations must give enough concern about raising the brand name of the organisation so that the branding dimensions can help them retain the pool of talented faculties. Pankaj Gupta et.al (2014) reveals that Employer Branding is a concept that is very crucial in the process of recruiting employees. Since recruiting and retaining talented employees is very critical for business success, companies must put full effort to be the right brand of employer. Several studies have been identified indicating the relationship between Employer Branding and Employee Engagement. A study by Piyachat, Chanongkorn and Panisa (2015) in Thai petroleum industry revealed a significant positive effect of Employer Branding on Employee Engagement. Hewitt (2011) said that the best employer is the one who promotes high engagement levels. Lee, Kim and Kim (2014) have also revealed a positive relationship between Employer Branding and Employee Engagement. Employer brand encourages the employees to put discretionary effort for uplifting the organization. A well-worked employer brand increases Employee Engagement and organisation's efficiency (Xia and Yang 2010). A study by Ahmad and Daud (2016) in Malaysian SME-ICT firms also tried to study the relationship between Employer Branding and Employee Engagement. The result revealed a positive significant relationship between Employee Engagement and Employer Branding. Organisation has to create its own brand value instead of making other people set their value. A good Employer Brand reduces the cost of hiring of prospective employees and also enhances Employee Engagement and retention (Ritson, 2002). Priyadarshi (2011) in her study revealed that Employer Brand image positively affects employee satisfaction, commitment and turnover levels. Lawler (2005) said that companies must keep their brand promises so that they can keep the employees engaged and retain them in the organisation. Fernon (2008) has summed up in their study that Employer Branding involves attracting and retaining the right people, help them get the brand value, keep up the brand promise so that they have their employees engaged and create a competitive advantage to the company. The positive relationship of Employer Branding on Employee Engagement has been revealed by various researchers like Botha et al., 2011 and Sokro, 2012. Vijayalakshmi, V. \& K Uthayasuriyan (2016) in their study identified the impact of Employer Branding image on Employee Engagement on banking employees. Jasveen Kaur and Ginni Syal (2017) revealed that effective employer brand is important for employee satisfaction. They also identified that a strong internal branding and external 
branding can influence the bank employees and make them happy with the organisation.

\section{Research Gap}

Many studies have been undertaken in several sectors of the industries relating to Employer Branding including Ahmad and Daud (2016), Khalid and Tariq (2015), Piyachat (2015), Chanongkorn and Panisa (2015), Hewitt (2011), Lee, Kim and Kim (2014), Xia and Yang (2010), Lawler, 2005, Botha et al., (2011), Sokro (2012), Priyadarshi (2011), Ritson (2002), Fernon (2008) etc. It is found that only limited studies are done in the banking sector related to Employer Branding. Though some of the studies have helped to better understand the concept of Employer Branding and build a theoretical platform for further studies, empirical evaluations are a few. Empirical studies covering `Employer Branding and Employee Engagement are not identified especially in the context of banking sector in the state of Kerala, India. Hence this study was done considering the three major banks in Kerala that is, SBI, ICICI, and HDFC. This study attempts to address the knowledge gap by empirically testing whether the Employer Branding affects engaging employees of a firm.

\section{Objectives of the Study}

This study aims to understand the relation between Employer Branding and Employee Engagement. The specific objectives that we intend to meet are as follows:

- To study the relationship between Employer Branding and Employee Engagement among bank employees of the selected banks.

- To know the relationship between Employer Branding dimensions and Employee Engagement.

- To find the relation between demographic variables and Employee Engagement.

\section{Hypotheses}

The research question that the researchers are trying to answer here is: whether there is a relation between Employer Branding and Employee Engagement. To answer that question, it was first necessary to identify the Employer Branding dimensions that organisations were adopting. Based on prior literature and researchers own observations, the following types of dimensions were identified: 1) Economic value 2) Social value 3) Developmental value and 4) Reputation value

The following hypotheses were developed by the researchers:

1. There is a significant positive relationship between Employer Branding and Employee Engagement

2. There is a significant positive relationship between Economic value and Employee Engagement

3. There is a significant positive relationship between Social value and Employee Engagement

4. There is a significant positive relationship between Developmental value and Employee Engagement

5. There is a significant positive relationship between Reputation value and Employee Engagement 
6. There is a significant positive relationship between Gender and Employee Engagement

7. There is a significant positive relationship between Experience and Employee Engagement

\section{Research Methodology}

The research method used for the study is quantitative in nature. The study is aimed at investigating the relationship between Employer Branding (EB) and Employee Engagement (EE) among employees of selected banks in Thiruvananthapuram district. The independent variable for the study is Employer Branding (Economic Value, Social Value, Developmental Value, and Reputation Value) and the dependent variable is Employee Engagement. 139 respondents from the selected banks were included in the study. Random sampling method was used to select 139 employees (82 female and 57 male) from these select banks. Self-administered structured questionnaire was used to collect data. The questionnaire has three parts.

The first part contains the demographic profile, the second part contains the EB scale and the third part contains the EE scale. EB part consists of 20 questions with dimensions like Economic Value, Social Value, Developmental Value and Reputation Value as the scale variables. Employee Engagement was analyzed using an EE scale developed by Gallup (1988). A total of 32 scale items were used in the questionnaire.

\section{Discussion}

The reliability was assessed by examining reliability coefficients. The data passed the internal consistency and reliability test as the Cronbach's alpha values were all greater than 0.832 . Kolmogorov-Smirnov test was used to identify the statistical normality of the data. The significance level was found to be less than .05 and thus the data was found to be normal data.

\begin{tabular}{|c|c|c|c|c|c|c|}
\hline \multicolumn{7}{|c|}{ Tests of Normality } \\
\hline \multirow{2}{*}{} & \multicolumn{2}{|c|}{ Kolmogorov-Smirnov } & \multicolumn{3}{|c|}{ Shapiro-Wilk } \\
\cline { 2 - 7 } & Statistic & Df & Sig. & Statistic & Df & Sig. \\
\hline EB & .227 & 139 & .000 & .875 & 139 & .000 \\
\hline \multicolumn{7}{|c|}{} \\
\hline & Kolmogorov-Smirnov & \multicolumn{3}{|c|}{ Shapiro-Wilk } \\
\cline { 2 - 7 } & Statistic & Df & Sig. & Statistic & Df & Sig. \\
\hline EE & .136 & 139 & .000 & .937 & 139 & .000 \\
\hline
\end{tabular}

Multiple regression analysis was used to analyse the significance of the variables. The analysis revealed that all the four dimensions of Employer Branding have a significant positive relationship with Employee Engagement. The overall regression model was significant for the predictor variables including (DV, SV, EV and RV) for $\mathrm{F}(1,138)=56.263$, the significance level $<0.05$ and $\mathrm{R}^{2}$ as 0.45 . The result indicates that Employer Branding explains $45 \%$ of the variance in Employee Engagement. 
Therefore, it can be analysed that the higher the Employer Branding, the higher is the Employee Engagement in the banking sector in Thiruvananthapuram district. It can be inferred that all the four dimensions of Employer Branding has a significant relation with Employee Engagement. This reveals that the four dimensions of Employer Branding predict Employee Engagement. This result supported the findings of studies by Ahmad and Daud (2016) and Lee, Kim and Kim, (2014) and Piyachat et al. (2015).

\begin{tabular}{|c|c|c|c|c|c|}
\hline \multicolumn{5}{|c|}{ Model Summary $^{\mathbf{c}}$} \\
\hline Model & R & R Square & Adjusted R Square & Std. Error of the Estimate $^{\text {Durbin-Watson }}$ \\
\hline 1 & $.492^{\mathrm{a}}$ & .242 & .237 & 5.62056 & \\
\hline 2 & $.673^{\mathrm{b}}$ & .453 & .445 & 4.79438 & .510 \\
\hline a. Predictors: (Constant), EV, SV, DV, RV \\
\hline
\end{tabular}

To investigate the relationship between Employer Branding (EB) and its dimensions with Employee Engagement, Karl Pearson's Correlation and Chi-square tests were used. The correlation between the two variables is found to be 0.556, which implies that they are positively correlated. The significance level was found to be less than 0.05 and hence the null hypothesis is rejected. It implies that EB and EE have a positive significant relationship with each other.

The significance and test result of EE and four dimensions of EB are shown below Table showing correlation of variables

\begin{tabular}{|l|c|c|c|}
\hline Correlation & Karl Pearsons Correlation & Significance & Test result \\
\hline EV and EE & 0.492 & 0.000 & Reject H0 \\
\hline SV and EE & 0.377 & 0.000 & Reject H0 \\
\hline DV and EE & 0.544 & 0.000 & Reject H0 \\
\hline RV and EE & 0.671 & 0.000 & Reject H0 \\
\hline
\end{tabular}

The result shows that there is a significant positive relationship between Economic value, Social value, Developmental value and Reputation value with Employee Engagement. Among the four predictors Economic Value and Reputation Value have the highest correlation with Employee Engagement and the lowest being Social Value.

To analyze the relation of demographic variables like gender and experience with Employee Engagement, independent sample t-test and one way ANOVA were used. For testing the significance of Gender on EE, independent sample t-test was done. The significance level was found to be $\mathrm{p}>0.05$ i.e. $\mathrm{P}=0.454$, so the null hypothesis was accepted and hence there is no significant relationship between Gender and Employee Engagement.

For testing the significance of Experience on EE, one way ANOVA test was done. The significance level was found to be $p>0.05$ i.e. $P=0.147$, so the null hypothesis 
was accepted and hence there is no significant relationship between Experience and Employee Engagement.

\begin{tabular}{|c|c|c|c|c|c|}
\hline \multicolumn{7}{|c|}{ ANOVA } \\
\hline & Sum of Squares & Df & Mean Square & F & Sig. \\
\hline & 666.578 & 4 & 166.644 & 1.732 & .147 \\
\hline Between Groups & 12894.055 & 134 & 96.224 & & \\
\hline Within Groups & 13560.633 & 138 & & & \\
\hline Total & Ond & & & \\
\hline
\end{tabular}

Oneway Eb By Experience

\section{Findings}

The study was conducted on 139 employees ( 82 female and 57 male) from the select Banks in Thiruvananthapuram district of Kerala. The study revealed a positive significant relationship existing between Employer Branding (EB) and Employee Engagement (EE). The analysis also indicated a positive significant relationship existing between all the dimensions of EB and EE. The result shows that there is a significant positive relationship between Economic value, Social value, Developmental value and Reputation value with Employee Engagement. Among the four predictors Economic Value and Reputation Value have the highest correlation with Employee Engagement and the lowest being Social Value. The relation of demographic variables like gender and experience with Employee Engagement was analyzed and found out that gender and experience have no significant relation with Employee Engagement. This study supports the findings of past studies done by Garg (2014) Robinson et al. (2004), Schaufeli, Bakker and Salanora (2006) and Yildirim (2008), in which they found no significant difference between Employee Engagement and gender. The results are not in line with the studies of Sprang Clark and Whitt-Woosley, (2007), Kong (2009) and Srivastava (2012) where they revealed that there exist differences in Employee Engagement between female and male workers.

\section{Limitations and Implications}

Despite having some useful findings, this study has some limitations. In this study, only a generalized concept of Employer Branding is considered including limited dimensions of Employer Branding. This study was done by collecting data from Thiruvananthapuram district of Kerala only. Hence comparisons with other regions of Kerala are not possible. From the study we could find out that most of the respondents are having a positive perception towards Employer Branding. Hence firms should try to develop more strategies to improve the branding dimensions of the firm. Since the study identified the positive relation of EB towards EE, the firms should be careful while framing new policies for Employer Branding dimensions.

\section{Conclusion}

The transformation in the banking sector and the huge growth of firms providing financial services had made employees and customers think of the identity or brand 
of a firm. The brand image or the reputation of the firm can make them more engaged and retained for a long run. The study was undertaken to find the relation between Employer Branding and Employee Engagement among selected bank employees of Thiruvananthapuram District of Kerala, India. The study is of preliminary nature and only two variables are included. The findings reveal a positive significant relationship between Employer Branding and Employee Engagement. It was observed that all the dimensions particularly Reputation Value of the firm can significantly influence employees to generate a discretionary behaviour of exhibiting engagement.

\section{References}

1. Barrow, S. (1990). 'Turning recruitment advertising into a competitive weapon'. Paper delivered at the CIPD Annual Conference, Harrogate, UK.

2. Ambler, T. and Barrow S. (1996). 'The employer brand'. The Journal of Brand Management, 4(3), 185-206

3. Backhaus, K. and Tikoo, S. (2004). 'Conceptualizing and researching Employer Branding.' Career Development International, 9(5), 501-517

4. Ahmad, N. A., \& Daud, S. (2016). 'Engaging People with Employer Branding. Procedia Economics and Finance, 35, 690-698.

5. Shazia Khalid and Shahnila Tariq. (2015).'Impact of employer brand on selection and recruitment process'. Pakistan Economic and Social Review. 53 (2), 351-372.

6. Rasheed, A., Khan, S., \&Ramzan, M. (2013). 'Antecedents and consequences of Employee Engagement:' The case of Pakistan. Journal of Business Studies Quarterly, 4(4), 183.

7. Hewitt, A. (2016). '2016 Trends in global Employee Engagement. Aon Corporation'.

8. Sullivan, J. (2004). 'Eight elements of a successful employment brand'. ER Daily, 23 February.

9. Kahn, W. A. (1990). 'Psychological conditions of personal engagement and disengagement at work'. Academy of Management Journal, 33, 692-724. doi: $10.5465 / 256287$

10. Bhatla, N. (2011). 'To study the Employee Engagement practices and its effects on employee performance with special reference to ICICI and HDFC bank in Lucknow'. International Journal of Scientific \& Engineering Research, 2(8), 17.

11. Larkin, E. (2009, October 30). 'The challenge of Employee Engagement.' Retrieved from http://www.hospitalitynet.org/news/4044076.html

12. Sharma, B. R., \& Anupama, R. (2010). 'Determinants of Employee Engagement in a private sector organization: An exploratory study.' Advances in Management, 3(10), 52-59.

13. Vance, R.J. (2006b). 'Employee Engagement and commitment: A guide to understanding, measuring and increasing engagement in your organization', Society for Human Resource Management, 1-45.

14. Gallup (2006). 'Engaged employees inspire company innovation', Gallup

Management Journal, http://gmj.

gallup.com/content/default.aspx?ci=24880\&pg=1. 
15. Chartered Institute of Personnel and Development (2007). 'How Engaged are British Employees?'. London: CIPD.

16. Buckingham, M., \& Coffman, C. (1999). 'First, break all the rules; what the world's greatest managers do differently'. New York: Simon and Schuster.

17. AON Empower Results. (2018). '2018 Trends in Global Employee Engagement.'

18. Harvard Business School Publishing. (2013). 'The impact of Employee Engagement on performance.'

19. Robinson, D., Perryman, S., \& Hayday, S. (2004).'The drivers of Employee Engagement'. Brighton, UK: Institute for Employment Studies. Retrieved from http://www.wellbeing4business.co.uk/ docs/ Article/20-20 Engagement/20research.pdf

20. Haid, M., \& Sims, J. (2008). 'Employee Engagement maximizing organizational performance'. Retrieved from http://www. Rightmanagement.it/it/thoughtleadership/research/employee-engagement maximizing-organizationalperformance. PDF

21. Evans Sokro (2012), 'Impact of Employer Brand on Employee Attraction and Retention'. European Journal of Business and Management, Vol.4, No.18, PP.164-173.

22. Jiang, T.T. and Iles, P. (2011). 'Employer brand equity, organizational attractiveness and talent management in the Zhejiang private sector, China'. Journal of Technology Management in China, 6(1), 97-110

23. Schlager et.al. (2011). 'The influence of the employer brand on employee attitudes relevant for service branding: an empirical investigation'. Journal of Service Marketing, 25(7), 497-508.

24. Collins, C.J. and Stevens, C.K. (2002). 'The relationship between early recruitment- related activities and the application decision of new labour- market entrants: A brand equity approach to recruitment'. Journal of Applied Psychology, 87(6), 1121-1133

25. Nisar Ahamad Nalband and Mohammed A. Al Awadh (2017). 'Employer Branding Practices in Saudi Arabian Banking Sector'. Journal of Management Research, Vol. 9, No.3 . DOI: 10.5296/jmr.v9i3.11223.

26. Amir Dabirian and Jeannette Paschen (2019). 'Employer Branding: Understanding Employer Attractiveness of IT Companies- Adapting IT Governance.' KTH Royal Institute of Technology, DOI: 10.1109/MITP.2018.2876980.

27. Sutherland, M.M., Tprricelli, D.G., \& Karg, R.F. (2002). 'Employer-of-choice branding for knowledge workers.' South African Journal of Business Management, 33(4), 13-20.

28. Fulmer, I. S., Gerhart, B., \& Scott, K. S. (2003). 'Are the 100 best better? An empirical investigation of the relationship between being a great place to work and firm performance.' Personnel Psychology, 56 (4), 965-993.

29. Rathore, H. (2014). 'Employer Branding: A synergistic and Reinforcing for an Organization.' IJTBM, 2014, Vol. No. 4, Issue No. IV, Oct-Dec

30. Pallavi Mehta and Khushboo Sharma (2014). 'Impact of Employer Branding on Retention of Employees of Management Institutes.' Journal of Research in Commerce \& Management, Vol. 2, Iss.2, pp.59-62. 
31. Pankaj Gupta, Ruchitta Patti, Shaveta Marwah (2014). 'Employer Branding: A Descriptive Study.' International Journal of Economic and Management Strategy, Vol.4, No.1, PP.1-10.

32. Piyachat, B., Chanongkorn, K., \& Panisa, M. (2015). 'The Relationships among Perceived Employer Branding, Employee Engagement, and Discretionary Effort.' Journal of Social Science, 9(1), 37-60

33. Hewitt, A. (2011). '2011 Trends in global Employee Engagement'. Aon Corporation.

34. Lee, Y. K., Kim, S., \& Kim, S. Y. (2014). 'The impact of internal branding on Employee Engagement and outcome variables in the hotel industry'. Asia Pacific Journal of Tourism Research, 19(12), 1359-1380.

35. Xia, Huang, and Liu Yang. 2010. 'The Employer Branding and employee performance.' Proceedings of the IEEE International Conference on Information Management. Innovation Management and Industrial Engineering (ICIII) 4: 536-38.

36. Ritson, M. (2002). 'Marketing and HR collaborate to harness employer brand power.' Campaign Magazine. Retrieved from http://www.marketingmagazine.co.uk /article/162068/ opinion-marketinghrcollaborate-harness-employer-brand-power

37. Lawler, E.E., III, (2005). 'Creating High Performance Organisations.' Asia Pacific Journal of Human Resources, 43.1, pp.10-17

38. Fernon, D., (2008). 'Maximising the Power of the Employer Brand.' Admap, pp. 49- 53.

39. Botha, Annelize \& Bussin, Mark \& Swardt, Lukas. (2011). 'An employer brand predictive model for talent attraction and retention'. SA Journal of Human Resource Management. 9. 10.4102/sajhrm.v9i1.388.

40. Vijayalakshmi, V. \& K Uthayasuriyan, Dr. (2016). 'Employer Branding Image on Banking Employees Attraction and Retention in Sivagangai District'. 5. 431434.

41. Jasveen Kaur and Ginni Syal, (March 2017). 'Determinative impact of employer attractiveness dimensions of Employer Branding on employee satisfaction in the banking industry in India.' Business Analyst, ISSN 0973-211X, 37(2), 129-144

42. Priyadarshi, Pushpendra. (2011). 'Employer Brand Image as Predictor of Employee Satisfaction, Affective Commitment \& Turnover'. Indian journal of Industrial Relations. 46. 510-22.

43. Garg, N. (2014). 'Employee Engagement and individual differences: A study in Indian context'. Management Studies and Economic Systems, 1(1), 41-50.

44. Schaufeli, W. B., Bakker, A. B. \& Salanova, M. (2006). 'The measurement of work engagement with a short questionnaire: A cross-national study. Educational and Psychological Measurement.' 66, (4), 701-716

45. Yildirim, I. (2008). 'Relationships between burnout, sources of social support and socio demographic variables.' Social Behavior and Personality, 36 (5), 603616.

46. Sprang, G., Clark, J. J. \& Whitt-Woosley, A. (2007). 'Compassion fatigue, compassion satisfaction, and burnout: Factors impacting a professional's quality of life.' Journal of Loss and Trauma, 12 (3), 259-280 
47. Kong, Y. (2009). 'A study on the job engagement of company employees'. International Journal of Psychological Studies, 1(2), 65-68.

48. Srivastava, S. (2012). 'Enhancing the quality of core work force through Employee Engagement: An empirical study on managers with respect to gender \&sectorial difference.' AIMA Journal of Management \& Research, 6(2/4).

\section{About Our Authors}

Anchu P R possesses 7 years of experience in teaching. She is currently working as Assistant Professor with Siena College of Professional Studies, Kochi, affiliated to Mahatma Gandhi University, Kerala. Her areas of interest include Organisational Behaviour and Research methodology among others. She is currently pursuing her doctoral research under the guidance of Dr. Santhosh P Thampi, Professor, School of Management \& Business Studies and Dean, Faculty of Management Science, in Mahatma Gandhi University, Kottayam, Kerala. She has published several papers in reputed journals and also presented papers in national level conferences. As a part of pursuit for academic excellence, she has attended several seminars, workshops and conferences.

Santhosh. P. Thampi is Professor, School of Management \& Business Studies and Dean, Faculty of Management Science, in Mahatma Gandhi University, Kottayam. He has produced $5 \mathrm{Ph}$. Ds, guided 16 M.Phil candidates, published 1 book, 60 papers in journals/ Proceedings and done 11 Educational video programmes in Management for CEC- UGC. Presently, in Mahatma Gandhi University, he is Syndicate Member; Director - Planning and Development; Convener - CSS Advisory Committee; Member - University Research Committee and Hon. Director - Inter University Centre for Organic Farming. He has visited Germany, Thailand, Sri Lanka, Kuwait, Bahrain, Qatar, Oman and United Arab Emirates. 